\title{
Ordstyrerbias i valgkampsdebatter
}

\author{
Af Anne Zafrir
}

\begin{abstract}
Public service tv-stationer har en central opgave som formidler imellem forskellige dele af samfundet, og under folketingsvalg indtager de en sarlig funktion som offentligt rum for demokratiet. Formålet er at sikre lige udtryksmulighed for alle partier og kandidater til at fremlagge deres politiske forslag for valgerne, som derudfra kan foretage deres valg. Forudsetningen herfor er, at tv-stationerne er balancerede.

Denne artikel viser, hvordan de to store public service tv-stationer, DR og TV 2, alligevel udøver politisk bias ved at lade ordstyrerne $i$ valgkampsdebatter favorisere en kandidat på bekostning af den anden. I artiklen gives der eksempler på, hvordan to statsministerkandidater fär tilbudt forskellige talevilkår fra ordstyrerne, og hvordan bias udfores på forskellige niveauer.
\end{abstract}

Public service tv-stationerne har interesse $\mathrm{i}$ at fremstå balancerede, da de er underlagt Radio- og fjernsynsloven, der foreskriver, at informationen, tv-stationerne sender ud, skal være saglig og upartisk. ${ }^{1}$ Derudover har medierne selv etableret sig i rollen som fjerde statsmagt, der vogter på demokratiet. $^{2}$ Det er en kontrakt, de har indgået med programdeltagere og publikum, og en vigtig del af deres identitet som nyhedsmedier. I det forhold er balance garanti for deres troværdighed.

Jeg undersøger "Topmødet" og "Den Sidste Duel", som var to direkte tv-valgkampsdebatter af en times varighed hver, der sendtes i november 2001. I debatterne var deltagerne daværende statsminister Poul Nyrup Rasmussen fra Socialdemokratiet og Anders Fogh Rasmussen fra oppositionspartiet Venstre. Ordstyrerne var Jes Dorph Petersen i "Topmødet" på TV 2 og Reimar Bo Christensen i "Den Sidste Duel” på DR1. "Topmødet" bestod af otte emner, hvor Dorph indledte hvert emne med at indkredse det og stille spørgsmål til begge kandidater, som derpå debatterede. På DRl var der tre emner, og Reimar Bo indledte hvert emne med spørgsmål til en af kandidaternes politiske forslag, hvorpå de gik i debat.

Til at analysere debatterne bruger jeg konversationsanalyse (eng.: Conversation Analysis), som arbejder på mikroniveau med at afdække samtalers sproglige organisering. ${ }^{3}$ Her anvendes udførlige og talenære udskrifter ${ }^{4}$ til at påvise deltagernes hand- linger og hvad, der foregår i en samtale. Konversationsanalyse beskriver ordstyrerens adfærd, når han er balanceret, med begrebet neutralisme:

- Journalisten fremsætter ikke støttende eller fjendtlige erklæringer, der kan opfattes som personlige holdninger, eller responderer følelses- eller holdningsmæssigt på de interviewedes tale. ${ }^{5}$

Ordstyrerens funktion i valgkampsdebatten er at generere information til publikum fra kandidaterne, og derfor består debatterne hovedsageligt af spørgsmål og svar imellem ordstyreren og kandidaterne og debat indbyrdes imellem kandidaterne. Ordstyreren åbner og lukker debatten og emner i debatten, og han vælger den næste taler. Dette forhold kaldes en turtagningsprocedure. At ordstyrerne stiller spørgsmål skaber et asymmetrisk forhold imellem dem og kandidaterne, som er centralt for udførslen af bias. De skaber rammerne, kandidaterne taler inden for, igennem måden, de opbygger emnerne på, hvilke spørgsmål de stiller, hvordan spørgsmålene formuleres og den rækkefølge, kandidaterne udspørges i.

\section{Alliancer imellem deltagere på TV 2}

I dette eksempel stiller ordstyrer Dorph spørgsmål til Fogh og Nyrup om, hvordan hospitalernes ventelister kan gøres kortere. Eksemplet er et af 
(Nr. 1) TV 2: "Topmøde". 11/11-2001. Dorph-Nyrup/Fogh. Sundhedspolitik.

\begin{tabular}{|c|c|c|}
\hline $\begin{array}{l}1 \\
2 \\
3 \\
4\end{array}$ & Fogh : & $\begin{array}{l}\text { [..] dem der ik har så mange penge er tvunget ind på } \\
\text { ventelisten og der sir vi det skal være socialt } \\
\text { retfærdigt det frie valg skal også være for den lille } \\
\text { mand }\end{array}$ \\
\hline $\begin{array}{l}5 \\
6\end{array}$ & Dorph: & hvorfor er det så galt at den lille mand får penge fra \\
\hline$f$ & & (.) og dermed også skåner den danske venteliste \\
\hline $\begin{array}{l}8 \\
9\end{array}$ & Nyrup: & $\begin{array}{l}\text { vi har i dag en en valgmodel når det gælder livstruende } \\
\text { sygdomme (.) øh (linjer ud)jeg kan ikke forstå }\end{array}$ \\
\hline 10 & & simpelthen (.) hvad det er der driver Venstre til at \\
\hline 11 & & sige nu skal vi investere $i$ nogle private sygehuse $i$ \\
\hline 12 & & stedet for at sige lad os dog koncentrere kræfterne om \\
\hline 13 & & de nioghalfems procent af vores sygehusvæsen som skal \\
\hline 14 & & som skal redde det her \\
\hline 15 & Dorph: & $=$ men det handler jo om sund konkurrence vil du sige \\
\hline $\begin{array}{l}16 \\
17\end{array}$ & & Anders Fogh ik sandt \\
\hline $\begin{array}{l}17 \\
18\end{array}$ & $\begin{array}{l}\text { Nyrup: } \\
\text { Fogh : }\end{array}$ & ] hvis jeg lige må gøre det færdigt \\
\hline $\begin{array}{l}18 \\
19\end{array}$ & Fogh : & [ja ford] \\
\hline $\begin{array}{l}19 \\
20\end{array}$ & Dorph: & så skal det være hur[tigt] \\
\hline 20 & Nyrup: & [det] handler forst og \\
\hline $\begin{array}{l}21 \\
22\end{array}$ & & fremmest om (.) det handler forst og fremmest om at få \\
\hline $\begin{array}{l}22 \\
23\end{array}$ & & uddannet nogen flere \\
\hline 23 & Dorph: & [det du ik uenig i] \\
\hline 24 & Nyrup: & [det blev jo de blev] [ jo skåret] ned $i$ antal (.) og \\
\hline 25 & Fogh: & {$[$ det jeg ik] } \\
\hline 26 & Nyrup: & det andet det er [..] \\
\hline
\end{tabular}

mange, hvor Dorph skaber en alliance med Fogh imod Nyrup ved at hjælpe ham over for Nyrup eller svække Nyrups taleposition.

\section{(Nr. 1) TV 2: "Topmøde". 11/11-2001. Dorph-Nyrup/Fogh. Sundhedspolitik.}

I Dorphs første tur allierer han sig med Fogh imod Nyrup. Han viser i linje 5-7 enighed med Foghs forslag og opstiller et forklaringsslot til Nyrup, hvor han skal redegøre for, hvorfor han er imod forslaget. Et slot er en plads, der er designet til at blive udfyldt med et bestemt indhold. ${ }^{6}$ Dorphs tur består af tre dele. Hoveddelen genererer uenighed imellem Fogh og Nyrup ved en footing ${ }^{7}$, han bruger til at skifte imellem at tale på egne vegne og til at tale på Foghs vegne. I footingen animerer Dorph Foghs tidligere tale; at den lille mand fär penge fra staten til at lade sig operere for eksempel $i$ udlandet, og dirigerer Nyrup til at tale specifikt herom. Ved at gengive Foghs holdning bruger Dorph footingen til at være balanceret, men han viser bias i de to andre dele af turen.
Den første del af turen er et spørgsmål om, hvorfor Nyrup mener, Foghs forslag er forkert. Dorph overdramatiserer ironisk Nyrups modstand ved så galt. Så udtrykker, at noget i høj grad er tilfældet, som latterliggør Nyrups uenighed. Sidste del af turen indeholder løsningen på problemet i emnet, skäner den danske venteliste, som Dorph selv kæder til Foghs forslag. Dorph viser enighed med Foghs forslag, fordi han bedømmer footingen positivt og derved beskriver forslaget positivt. Han bedømmer Nyrup negativt, da han skal forholde sig uenigt til footingen ved den forklaringsslot, Dorph skaber for ham. Der skal Nyrup forholde sig til Foghs politiske standpunkt som rigtigt og en løsning på problemet. Nyrup skal ikke bare være uenig, men skal redegøre for, hvorfor han er uenig. Siden Dorph præsupponerer, at forslaget løser problemet, lades Nyrup alene med uenigheden. Det er rettet imod publikum, da de også præsupponeres at være enige.

Dorph fortsætter alliancen med Fogh og enigheden med hans forslag i linje 15-16, hvor han al- 
lokerer tur til Fogh, som er designet til at generere uenighed. Dorph giver indholdet ved det handler jo om sund konkurrence, og med jo præsupponerer han, at det er indlysende. Sund farver konkurrence positivt, hvormed Dorph viser sin sympati for det.

Nyrup fortsætter med sin løsning på ventelisteproblemet i linje $20 \mathrm{og}$ anklager Fogh for at have skåret ned på læger og sygeplejersker. Men Dorph afviser anklagen og løsningsforslaget som trivielt $\mathrm{i}$ linje 23 ved at spørge Fogh i overlap, om han er uenig. At Dorph taler med Fogh i overlap, viser alliancen imellem dem, fordi de holder en samtale, mens Nyrup taler, og viser, at Nyrups tur og dens indhold er uvigtigt.

Man kan argumentere for at Dorph med sine handlinger ikke er substantielt enig med Fogh, men bare bruger en interessant interviewform, som spidder Nyrup. Men for at det ikke skal ses som bias imod Nyrup, ville man forvente, at den samme interviewform blev anvendt imod Fogh, hvilket ikke sker.

\section{Kampen om taletid på DR1}

Ordstyreren administrerer kandidaternes taletid og markerer, hvis han ønsker en kort tur, eller at turen stopper. ${ }^{8}$ Taleturenes længde afgøres ikke (åbenlyst i hvert fald) med stopur, for at kandidaterne får lige meget tid. I stedet sker det i et samspil mellem kandidaternes projicering af en turs indhold, hvornår turen slutter og ordstyrerens tegn til, at den skal slutte. Projicering henviser til, at Nyrup eller Fogh opbygger deres ture med sproglige enheder, deltagerne kan genkende og derfor delvist forudsige. ${ }^{9}$ Igennem projicering kan ordstyreren Reimar Bo, Nyrup og Fogh forudsige, hvornår en tur slutter, og hvornår man kan forsøge talestart. ${ }^{10}$ Reimar Bo orienterer sig i debatten imod steder i Nyrups og Foghs ture, der er projicerede relevante som afslutninger og markerer, at her skal afslutningen falde. Men Nyrup og Fogh kan sløre markeringerne eller handle for at beholde ordet, fordi hvert nyt element i en tur bidrager til forsinkelse eller fremme af turens slutning. Projiceringen bliver tydeligere jo mere turen realiseres, og den mulige afslutning kan forudsiges med større og større præcision. ${ }^{11} \mathrm{Jeg}$ har fundet fire metoder, ordstyreren signalerer talerskifte med i debatterne:

\section{Figur 1}

1. Visuelt signal til taler.

2. Forsøg på talestart i talers pauser.

3. Tale i overlap med taler.

4. Producer kan slukke for talers mikrofon.

Reimar Bo styrer turskifte i debatten med et visuelt signal ved at løfte hånden tættest på taleren. Han kan derpå løfte den anden hånd for at vise, at modkandidaten skal være klar til at få turen, men vente til et relevant sted. Det næste eksempel fra "Den Sidste Duel" på DR1 er fra emnet "Ulande", hvor Reimar Bo har stillet spørgsmål til Venstres forslag om at skære en halv milliard fra ulandsbistanden. Han har derpå ladet Nyrup overtage angrebet af Fogh. Til slut i emnet er Nyrup tildelt en kort tur og får tegn fra Reimar Bo om at afslutte visuelt ${ }^{12}$ og verbalt:

\section{(Nr.2) DR1: Den sidste Duel. 17/11 2001.} Reimar Bo-Nyrup/Fogh. Ulande. (se side 30)

Reimar Bo løfter hånden under Nyrups tur og signalerer afslutning. Derpå signalerer en indånding fra Fogh talestart i linje 5. Reimar Bo løfter den venstre hånd imod Fogh, som kan være et signal til Fogh om at vente, til Nyrups tur er færdig, og Reimar Bo tager armene ned. Nyrup har projiceret en mulig afslutning ved ordene så ville det vare et utroligt darrligt signal i linje 2, hvor afslutningen kunne være: "at sende". Nyrup forlænger sin tur med en del underordningsled (når vi, som vi i linje 2-3), hvorunder Foghs indånding kommer, også som et signal om, at Nyrup skal slutte. Det overgangsrelevante sted i Nyrups tur er, at enden på den projicerede afslutning kommer (at vi så ..sagde), og det ved Nyrup nu bliver til et turskifte. Men i stedet for at slutte, som Reimar Bo har styret, laver Nyrup et rush-through i linje 8, som lukker overgangsrummet ved hurtigt at passere det. ${ }^{13}$ Nyrup fortsætter sin tur med jeg vil gerne sige. Reimar Bo prøver at bryde ind i overlap (meme hrm), der er en protest imod, at Nyrup ikke samarbejder om Reimar Bos styring af talerskifte, ved at $m e$ formentlig er et men, som er en modsætning til det, der sker. Samtidig starter Fogh en tur i linje 10 (det det), men stopper, og Nyrup taler henover seks mulige færdiggørelsespunkter. ${ }^{14}$ De sidste fire er efter en projiceret afslutning med derfor i linje 11 , der viser, at det næste er begrundet i det for- 
(Nr.2) DR1: Den sidste Duel. 17/11 2001. Reimar Bo-Nyrup/Fogh. Ulande.

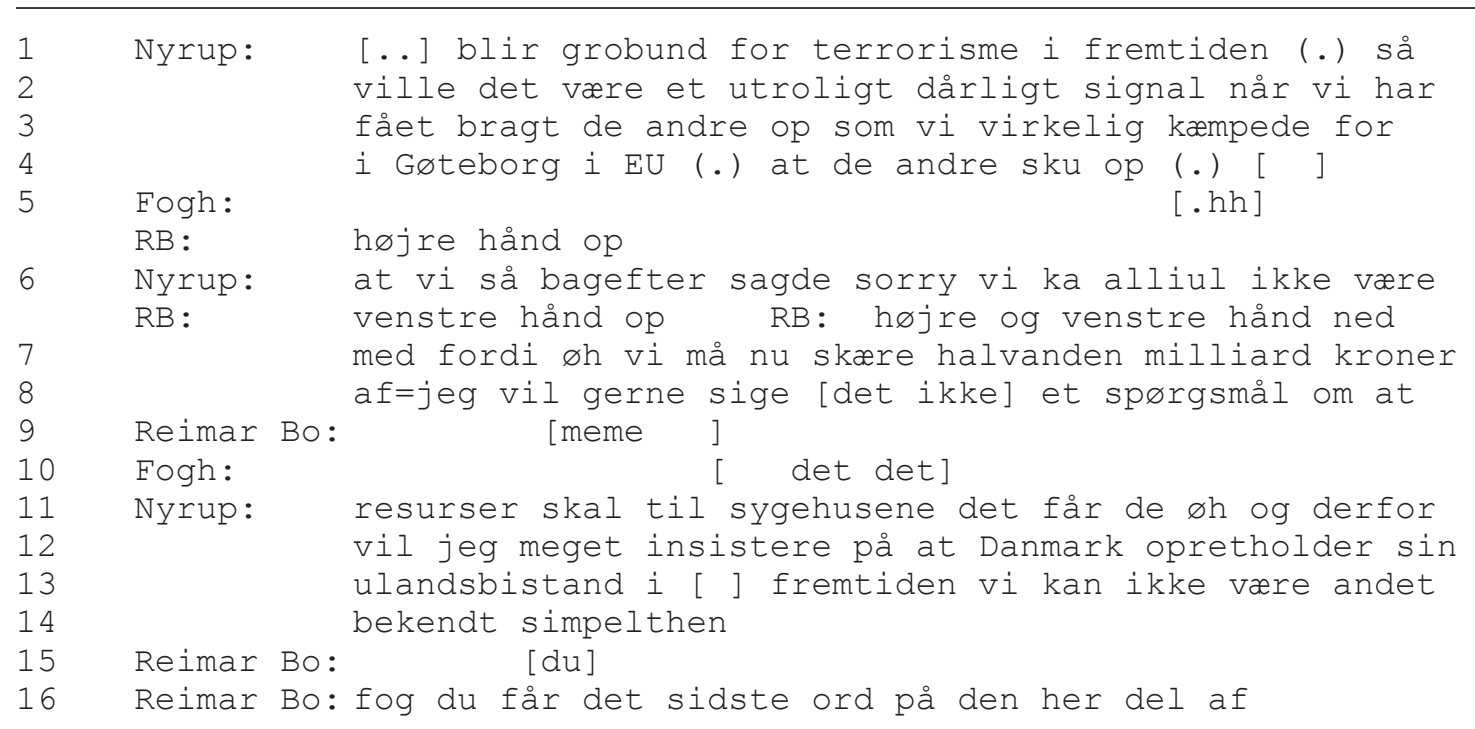

udgående og opsummerer det. Den tidligst mulige afslutning er efter ulandsbistand, som Reimar Bo orienterer sig imod ved at starte en allokering til Fogh $(d u)$, som først fuldføres efter yderligere tre mulige færdiggørelsespunkter. Således modarbejder Nyrup igen Reimar Bos styring og beholder sin tur.

Eksemplet viser ordstyrers reaktion på, at Nyrup tager magten over debatten ved at forlænge sine ture og spærre for Fogh, efter Reimar Bo markerer turskifte. Eksemplerne siger meget om Reimar Bos styring, fordi han ikke griber markant ind i Nyrups tur. Da Nyrup ikke samarbejder med Reimar Bo om at afgive sin tur, styrer Nyrup interaktionen disse steder. Samtidig appellerer Fogh til Reimar Bo om at få tildelt turen og søger derved også indflydelse på Reimar Bos styring. Det viser Reimar Bo som en svag ordstyrer, som ikke opretholder balancen imellem Nyrups og Foghs synspunkter, og det bliver til en form for bias.

På den anden side viser Reimar Bo også bias ved, at han giver fem ud af syv sidste ture, der kommer, når et emne afsluttes, til Fogh. De adskiller sig fra andre ture ved, at ordstyreren bagefter skifter emne eller lukker samtalen. Den, der er den sidste til at fremlægge sit synspunkt, er i en god position, fordi det kommer til at stå uimodsagt.

\section{Designet af valgkamps- debatten inden afvikling}

Eksempler på bias har foregået i debatternes løbende udvikling før, under og efter kandidaternes taleture. Måden, valgkampsdebatten designes inden dens udførsel, kan også lede til bias. Jeg har fundet tre overordnede områder, hvor det forekommer:

\section{Figur 2}

1. Emnernes politiske vinkling.

2. Emnernes sproglige opbygning.

3. Kandidaternes talepositioner i debatten.

Public service tv-stationerne kan lægge en politisk vinkel på emnerne, der styrer, hvordan kandidaterne kan forholde sig til dem. Det kan være problematisk, siden kandidaterne inden valgkampsdebatterne har positioneret sig politisk i forhold til emnerne. Hvad betyder det for eksempel, hvis mange valgemner handler om enkeltsager?

Journalisterne kan også opbygge emnerne sprogligt på en måde, der styrer, hvordan kandidaterne kan forholde sig til dem. I "Topmødet" blev hvert emne præsenteret som et problemområde, 
som kandidaterne gav hver sin løsning til. Den problemorienterede fremlæggelse er en del af mediets logik, så det er en naturlig indgangsvinkel til emnerne. Et spørgsmål skaber konteksten for svaret, og når udgangspunktet er et problemområde, står oppositionen stærkere, fordi den vil lave om på politikken, der føres. Det passer bedre som løsning end at fastholde praksis. For den siddende regering er det svært at tale om løsninger på problemer, for hvorfor har de så ikke løst dem for lang tid siden? Dette forhold er forbundet til kandidaternes identiteter som forsvarer og angriber af statsministerposten.

Det tredje område, hvor tv-stationerne kan vise bias, er igennem de talepositioner, de tildeler i debatten. ${ }^{15}$ Valgkampsdebatterne udføres igennem spørgsmål fra ordstyrerne og svar fra kandidaterne. Det betyder, at deltagernes turtyper hovedsageligt er fastlagt på forhånd, og man ved, hvem der taler hvornår. Det kan ordstyrerne bruge til at positionere kandidaterne sekventielt i forhold til hinanden. Er man først til at fremlægge, er det svært at kritisere modparten, fordi hans forslag først gøres relevant, efter han har fremlagt. Er man nummer to, kan man angribe modpartens politik.

\section{Hvem åbner debatten?}

I debatten imellem kandidaterne, der kommer efter ordstyrerens spørgsmål til dem, kan Nyrup og Fogh præge interaktionens forløb ved at organisere den i turpar $^{16}$, hvor de for eksempel anklager eller stiller spørgsmål til modparten. I det forhold er det vigtigt, hvem der producerer overgangen til debat og kommer med den første turpardel, for han præger debattens indhold. Producerer man første del af et turpar, skal den anden del af turparret leveres for ikke at være mærkbart fraværende, og derpå kommer turen tilbage til producenten. ${ }^{17}$ I alle vigtige emner, som får den højeste prioritet i form af længst tid og placering i "Topmødet" på TV 2, stiller Dorph først spørgsmål til Nyrup, som på grund af sin tildelte placering ikke kan forholde sig til Foghs svar. Da de derpå skal stilles til Fogh, får Nyrup mindst mulighed for at starte debatten i forbindelse med sin tur. Debatten bliver nemlig til i en forsættelse af den kandidats tur, som sidst blev stillet et spørgsmål. Fogh har omvendt den bedste mulighed og kan også angribe det, Nyrup har sagt. Hvis Fogh ikke benytter sig af muligheden, vil turen gå tilbage til Dorph, og derfor står Nyrup sidst i køen til tur, når der er overgang til debat. I det næste eksempel har Nyrup på trods heraf opnået positionen til at gå i debat, men det ændrer Dorph bagefter.

I eksemplet styrer Dorph uenigheden i debatten imellem Fogh og Nyrup ved at ændre deres sekventielle position og skabe en alliance med Fogh. Inden har Dorph stillet spørgsmål til Nyrups og Foghs politiske forslag til at løse et problem med familiesammenførte udlændinge. I et af Nyrups svar, om han vil røre ved retskravet for familiesammenføring, skifter Nyrup til debat ved at anklage Fogh for at ville gøre dette (ikke vist). Dermed opnår Nyrup, på trods af sin sekventielle placering sidst i køen til at gå i debat, denne position, og de to kandidater går i debat. Efter Fogh afviser anklagen, får Nyrup turen igen og stiller et nyt spørgsmål til ham, men sanktioneres af Dorph, der genindfører interviewproceduren via et spørgsmål:

(Nr. 3) TV 2: Topmøde. 11/11-2001.
Dorph-Nyrup/Fogh. Udlændinge. (se side 32)

Dorphs første tur har tre funktioner. Den afbryder uenigheden imellem Nyrup og Fogh ved at genindføre interviewproceduren, hvor Dorph stiller spørgsmål til Nyrup i stedet for Nyrup til Fogh. Den beskytter Fogh imod Nyrup ved at trække ham ud af forsvarspositionen, Nyrups angreb satte ham i (linje 1-8). Og den angriber og udfordrer Nyrup ved at pege tilbage imod den anklage, han rettede imod Fogh om Venstres holdning til retskravet, og vise den samme holdning i Socialdemokratiet (hvad er forskellen på det og det, linje 19). Det gør Dorph balanceret med en footing, som er stærk, da den er i samme kategori, som Nyrup introducerede om Birthe Rønn Hornbæk (linje 1), den henviser til Nyrups minister (linje 10, 11, 17), er tæt på i tid (forleden) fra et direkte interview i nyhederne (linje 10) og dermed officiel. Spørgsmålet er fjendtligt ${ }^{18}$, fordi det påpeger diskrepans imellem det, Nyrup $\mathrm{og}$ hans minister siger. Og det fungerer som en udfordring, der udsætter Nyrup og Socialdemokratiet for publikums fordømmelse, hvis han ikke kommer med en forklaring.

Dorph vender situationen om ved at ændre de sekventielle placeringer i interaktionen, og Nyrup ender i forsvarsposition. Dorph allokerer i linje 32 tur til Fogh og indikerer den fælles enighed, så Fogh kan bekræfte Dorphs anklage imod Nyrup om diskrepans. I eksemplet griber Dorph ind i den sekventielle udvikling af interaktionen og skifter 
(Nr. 3) TV 2: Topmøde. 11/11-2001. Dorph-Nyrup/Fogh. Udlændinge.

\begin{tabular}{|c|c|c|}
\hline $\begin{array}{l}1 \\
2 \\
3 \\
4 \\
5 \\
6\end{array}$ & Nyrup: & $\begin{array}{l}\text { jamen hv hvordan vil du egentlig gøre det jeg har } \\
\text { forstået på Birthe Rønn (.) at du vil nu ind og se på } \\
\text { cpr registeret og så vil du sige arh lad os nu lige se } \\
\text { (.) hvis bedsteforældrene og tipoldeforældrene (.) har } \\
\text { været fra den samme etniske minoritet så går den ikke } \\
\text { længere [(.) ] der det er det er det det I vil }\end{array}$ \\
\hline 7 & Dorph: & [Poul Nyrup] \\
\hline 8 & Nyrup: & fordi[ det det ka jo ikke] la sig gøre jo[ i øvrigt \\
\hline 7 & Dorph: & [Poul Poul Nyrup må] (.) \\
\hline 8 & Nyrup: & så det er meget u] sympatisk \\
\hline $\begin{array}{l}9 \\
10\end{array}$ & Dorph: & $\begin{array}{l}\text { lige citere din] (.) må jeg citere din } \\
\text { egen indenrigsminister forleden i øh i nyhederne }\end{array}$ \\
\hline 11 & & [ ] der sagde (.) i et direkte interview der sagde Karin \\
\hline 12 & Nyrup: & {$[j a]$} \\
\hline 13 & Dorph: & Jespersen .h det er uholdbart vi overvejer særlige krav \\
\hline 14 & & og aldersgrænser for tilflyttere fra Tyrkiet å Pakistan \\
\hline 15 & & og det tidligere Jugoslavien der systematisk rejser \\
\hline 16 & & hjem og henter deres ægtefælder i forældrenes \\
\hline 17 & & hjemlande[ ]det sagde Karin Jespersen [ \\
\hline 18 & Nyrup: & [ja] \\
\hline 19 & Dorph: & hvad er [forskellen på ] det og det \\
\hline 20 & Nyrup: & [det jo det sam] \\
\hline 21 & Nyrup: & forskellen er at hun tar jo udtrykkeligt afstand fra \\
\hline 22 & & (.) og gøre forskel (.) mellem landende det har hun ås \\
\hline 23 & & sagt sku du bare lige finde det rigtige (.) det rigtige \\
\hline 24 & & ] det Karin Jespersen sir (.) det \\
\hline 25 & Dorph: & [jam det] \\
\hline 26 & Nyrup: & er (.) det ville være i modstrid [(.)] med \\
\hline 27 & Fogh : & {$[\mathrm{hrm}]$} \\
\hline 28 & Nyrup: & internationale regler (.) om at vi sir (.) tre landes \\
\hline 29 & & nationaliteter vil vi ikke acceptere til forskel fra \\
\hline 30 & & andre det direkte i modstrid med de internationale \\
\hline 31 & & [konventioner det sir Karin \\
\hline 32 & Dorph: & [men men det er i begge to enige om Anders Fog \\
\hline 33 & Nyrup: & ås $\quad$ jo ] \\
\hline 34 & Dorph: & Rasmussen] \\
\hline
\end{tabular}

positionerne for Fogh og Nyrup. Det gør han balanceret ved at stille et spørgsmål til Nyrup. Men samtidig skaber han en alliance med Fogh imod Nyrup, fordi han ikke nøjes med at stoppe uenigheden, som Fogh lider under, men fortsætter den ved at udføre en anklage imod Nyrup og derpå give Fogh tur til at fortsætte den. Dermed er Nyrup tilbage i position som den sidste, der kan gå i debat, og Dorph sætter Fogh i positionen som anklager af Nyrup. Selv om handlingen er balanceret, udfører den sekventielt bias. I stedet kunne Dorph have afsluttet uenigheden og vendt tilbage til turtagningsproceduren.

\section{Handlings- oppositionssekvenser}

Reimar Bo skaber på DR1 en alliance med Nyrup, hvor han først angriber Fogh og bagefter lader Nyrup overtage angrebet, så der kommer et asymme- 
trisk forhold imellem dem med Fogh i den svage taleposition. Det opretholdes i den efterfølgende debat imellem kandidaterne, da den er organiseret i turpar, hvor Nyrup anklager og angriber Fogh. Reimar Bo arbejder en del på at opnå asymmetrien imellem Fogh og Nyrup, som viser, at oppositionen er et mål i sig selv. Det har indflydelse på vinklingen af emnerne og handlingerne, kandidaterne kan foretage.

Reimar Bo frembringer ubalancen ved at skabe handlings-oppositionssekvenser ${ }^{19}$ imellem kandidaterne. En handlings-oppositionssekvens opstår, når en taler behandler det forrige udsagn som diskuterbart. Det betyder, at det er i anden tur, at sekvensen defineres som en handlings-oppositionssekvens, og første tur potentielt kan indeholde hvad som helst. ${ }^{20}$

Handlings-oppositionssekvensen i eksemplet består af to dele. I første del introducerer Reimar Bo Foghs valgforslag og stiller kritiske spørgsmål til det. Således opfylder han normen i politisk journalistik om at skabe kritisk distance til deltagerne. ${ }^{21}$ Det sætter Fogh i en position som forsvarer, hvilket styrer indholdet af hans svar. Reimar Bo gør problemer ved Foghs forslag relevante, hvilket han viderefører til anden del af sekvensen ved at generere uenighed fra Nyrup, der overtager Reimar Bos rolle som angriber.

\section{(Nr. 4) DR1: Den sidste Duel. 17/11 2001. Reimar Bo-Nyrup/Fogh. Sundhedspolitik.}

I første del styrer Reimar Bo emnet og Foghs taleposition i et hovedspørgsmål og to kritiske opfølgningsspørgsmål til Fogh, som skaber problemet, Nyrup overtager i anden del. Emnestyringen er tydeligst i hovedspørgsmålet, hvor Reimar Bo udpeger informationen, han efterspørger (du lover valgfrihed $i$ hospitalssektoren, linje 1-2), og i et efterhængt ja-nejspørgsmål (betyder det), hvor Reimar Bo bestemmer, hvilken del af valgforslaget Fogh skal tale om (at man kan få de penge..., linje 2-3). Reimar Bo indsnævrer emnet i opfølgningsspørgsmålene til forskellen i pris på et privat og et offentligt hospital. De tager kritisk stilling til Foghs svar på hovedspørgsmålet. Det første skaber tvivl om Foghs viden (er du sikker på). Det er kombineret med et udsagn, der giver denne viden (fordi der findes jo), som er rettet mod publikum. Det viser diskrepans i forslaget (så er de offentlige takster...jo lavere), der afsluttes med spørgsmålet hvad så med resten? Reimar Bo siger jo, der viser, at han siger noget indlysende. Diskrepansen udfordrer Fogh og gør emnet til problemer ved forslaget, som sætter ham i forsvarsposition.

I forsvarsposition er Fogh dirigeret til at tale om løsninger på de rejste problemer (ja og den det problem loser vi...linje 19). Reimar Bo efterspørger derpå et svar, der præsupponerer svagheden i, at Foghs forslag er uafprøvet. Ka du så nevne det hospital (linje 23-24) udfordrer Fogh ved at spørge til hans evne til at give et eneste eksempel og præsupponere, at han ikke kan.

Emnestyringen fastlægger Venstres forslag som problem i stedet for ventelister som et samfundsproblem. Reimar Bo skaber med den kritiske distance skepsis hos publikum over for forslaget, som bedømmer Fogh ud fra, om han kan forsvare sig. Hans ture er orienteret imod et forsvar af valgforslaget. For eksempel orienterer han sig imod, at det centrale i Reimar Bos spørgsmål er, om der kommer penge imellem patient og hospital ved at gentage i hvert svar, at det ikke sker (se linje 4, 7-9, 20-21, 29-30).

I anden del af handlings-oppositionssekvensen styrer Reimar Bo, at Nyrup overtager angriberrollen fra første del. Han konstruerer skepsis, som han kombinerer med positive egenskaber for at generere en ironisk modsætning. Det sker ved, at han stiller Nyrup et hypotetisk spørgsmål. ${ }^{22}$ Det er baseret på en antagelse, der ikke er bevist og derfor tvivlsom. Det består af et interrogativ (ville det $i k k e$ ), hvor modalverbet viser det hypotetiske, som gentages med (hvis nu). Derpå konkretiseres det $\mathrm{i}$ eksemplet (en metalarbejder...), som beskriver Venstres forslag. Spørgsmålet har to formål. Det ene er forbundet til Reimar Bos emnestyring, hvor han i kombinationen af et hypotetisk spørgsmål med en ironisk positiv beskrivelse (med opadgående intonation) viser en grundlæggende antagelse om Venstres forslag: "når noget er tvivlsomt, er det ikke en god ide". Reimar Bo forholder sig negativt og skeptisk til Foghs position i valgkampen som den, der skabte forandring med nye ideer. Hans gengivelse af Foghs forslag er ikke korrekt, fordi han heri netop placerer penge imellem patient og hospital (så vil jeg godt legge måske trettentusind oveni), selvom han har afprøvet informationen tre gange. Dermed viser han skepsis over for Fogh, da han ikke accepterer Foghs information. Han fastholder emnet som problematisk, hvilket betyder, at Nyrup også kan behandle det sådan. Det andet formål er forbundet til den sekventielle udvikling, hvor Rei- 


\section{Nr. 4) DR1: Den sidste Duel. 17/11 2001. Reimar Bo-Nyrup/Fogh. Sundhedspolitik.}

Reimar Bo: .h Andres Fogh (.) du lover valgfrihed i hospitalssektoren betyder det at man kan få de penge af det offentlige som en behandling koster et andet sted

Fogh: ja den valgfrihed vi foreslår den koster ikke en krone for patienten (linjer ud) og pengene føller så med patienten hen til det sted hvor behandlingen finder [ sted og ] på en måde så der overhovedet ikke kommer

Reimar Bo: [men men] [ men er du] er du sikker på

Fogh: penge mellem patient [og hospital]

Reimar Bo: fordi der findes jo nogen offentlige takster og der findes jo nogen tilgængelige prislister [ ] på

Fogh : [ja]

Reimar Bo: privathospitalerne (.) og når man kigger henover det [ ] så er de offentlige takster de penge man så ku Fogh: $\quad[\mathrm{hrm}]$

Reimar Bo: få de: jo lavere end det det koster på et privathospital [ ] hva så med resten

Fogh: $\quad[j a]$

Fogh: ja og den det problem det løser vi på den måde at (linjer ud)så derfor (.) kan vi sige fuldstændig klart

Reimar Bo: (.) der bliver ikke penge mel[lem ] patient og hospital

Reimar Bo: ka du så nævne det hospital der vil gå ned på de priser

Fogh: $\quad$. h det har vi hørt at der er flere privathospitaler der er interesserede $i$ for at være med i fritvalgsordningen og ve de ik (.) så er det deres egen sag men altså forudsætningen for at være med $i$ vores fritvalgsordning er at man ikke tar penge fra patienterne

Reimar Bo: .h Nyrup m m ville det ikke være en god ide hvis nu for eksempel en metalarbejder står på venteliste [til] en hofteoperation [ ] og han siger jamen Nyrup: $\quad[\mathrm{hm}]$ [hm]

Reimar Bo: ku jeg bare få de (.) seksoghalvtredstusind som det koster fra det offentlige [ ] med så vil jeg godt

Nyrup: [hm]

Reimar Bo: selv lægge måske trettentusind oveni og så blive behandlet nu

Nyrup: hm (.) vi øh har vurderet [ ] det forslag meget nøje Fogh:

Nyrup: [hrm ]

jeg har nær sagt hvis det kom til at fungere fornuftigt (.) og vores metalarbejder som du var inde på øh rent faktisk blev behandlet hurtigere og bedre (.) så ville jeg ikke tøve [..] 
mar Bo via ironien vil generere uenighed med den forrige sekvens via: ville det ikke vare en god ide. Det er underforstået igennem konteksten, at det synes Nyrup ikke, da han og Fogh er modstandere.

Nyrup samarbejder om styringen og indgår i et fællesskab med Reimar Bo om oppositionen imod Fogh. Det udtrykker han med anerkendelsesmarkører $(h m)$ under Reimar Bos spørgsmål og ved, at han overtager Reimar Bos ironi og behandler Venstres forslag som en god ide. I sit svar (ikke medtaget) udtrykker Nyrup Reimar Bos grundlæggende antagelse om, at noget, der er tvivlsomt, ikke er en god ide. Dermed drager han en konsekvens af Reimar Bos emnestyring: at Foghs forslag ikke handler om en politisk løsning på et samfundsmæssigt problem, men at det er en unødvendig ide, fordi ventelister som samfundsproblem ikke er gjort relevant som emne. Derpå allokerer Reimar Bo tur til Fogh (ikke medtaget), så han kan svare Nyrup, og opretholder således handlings-oppositionssekvensen.

\section{Afslutning}

Jeg har vist fire eksempler på ordstyrerbias i valgkampsdebatterne imellem statsministerkandidaterne år 2001. Eksemplerne er en del af mange, som på TV 2 var rettet ensidigt imod Nyrup og på DR 1 stort set ensidigt imod Fogh.

Man kan argumentere for, at det er journalistiske greb, der udøver kritisk distance. Det gør hele interaktionen mere interessant at se, fordi emnerne bliver sat på spidsen, politikerne bliver udfordret og ikke bare kommer med deres forberedte udsagn. Men når den kritiske distance kun udføres imod en kandidat, skabes en slagside i debatten, som viser, hvad man kan kalde en skjult bias. Denne bias opnås ved en systematisk gentagelse af store og små handlinger rettet imod en kandidat. Hvis der kun var få eksempler, eller hvis de var rettet imod begge kandidater, ville det ikke være problematisk. Her vil jeg indføje, at jeg ikke mener, at ordstyreren skal behandle de to kandidater helt ens. Den ene er forsvarer og den anden angriber af statsministerposten, som fra starten giver dem forskellige udgangspunkter at kommunikere fra i valgkampen.

Konversationsanalyse er ideel til at finde denne skjulte bias, fordi dens fokus er på mikroniveau, hvor man systematisk undersøger deltagernes handlinger og de konsekvenser, de har for valgkampsdebatternes forløb. Konversationsanalyse udelader dog på grund af sin kontekstforståelse, som ser på helt lokale områder i en debat, potentielt vigtige områder til at påvise bias. Konversationsanalyse har også svært ved at forholde sig til konsekvensen af akkumulerede handlinger, for eksempel det, at partiske handlinger hele tiden rettes imod den samme person, eller det forhold, at deltagerne kender hinanden på forhånd og er forudindtagede over for hinandens måder at debattere eller interviewe på.

I den forbindelse kan man overveje, om de to valgkampsdebatter danner kontekst for hinanden. Formentlig har DR skelet til TV 2's udførsel af "Topmødet", da de skulle opbygge "Den Sidste Duel" en uge efter.

\section{Litteraturliste}

Antaki, C. (1994): "Explanation slots". I Explaining and Arguing. The Social Organization of Accounts (kapitel 5). London: Sage.

Antaki, C. \& Widdicombe, S. (1998) (red.): Identities in talk. London: Sage Publications.

Atkinson, J. Maxwell: "Displaying neutrality: formal aspects of informal court proceedings". I P. Drew \& J. Heritage (eds.), Talk at Work (s. 199-211). Cambridge University Press.

Bilmes, J. (1999): "Questions, Answers, and the Organization of Talk in the 1992 American Vice-Presidential Debate: Fundamental Considerations". I Research on Language and Social Interaction (1999). Nr. 32, s. 213-42.

Clayman, S.E. (1988/89): "When the medium becomes the message: The case of the Rather-Bush encounter". I Research on Language and Social Interaction. Vol. 22, s. 241 272.

Clayman, S.E. (1992): "Footing in the achievement of neutrality: The case of news-interview discourse". I P. Drew \&J. Heritage (eds.), Talk at Work (s. 163-198). Cambridge University Press.

Clayman, S. \& Herritage, J. (2002): The Newes Interview. Fournalists and Public Figures on the Air. Cambridge University Press.

Drew, P. \& Heritage, J. (eds.) (1992): Talk at Work. Cambridge University Press.

Drew, P. (1978): "Accusations: The Occasioned Use of Members Knowledge of Religious Geography in Describing Events". I Sociology. Vol. 2, nr. 1. Januar 1978, s. $1-22$

Gaik, F. (1992): "Radio talk-show therapy and the pragmatics of possible worlds". I A. Duranti \& C. Goodwinn (red.), Rethinking context. Language as an interactive phenomenon. Cambridge University Press.

Goodwin, C. (1979): "The Interactive Construction of a Sentence in Natural Conversation". I Psathas (ed.), Everyday Language: Studies in Ethnomethodology. Irvington Press.

Greatbatch, D. \& Heritage, J. (1991): “On the institutional Character of Institutional Talk: The case of News In- 
terviews". I: D. Boden \& D. Zimmerman (eds.), Talk and Social Structure: Studies in Ethnomethodology and Conversation Analysis. Cambridge. Polity Press.

Greatbatch, D. (1992): "On the management of disagreement between news interviewees". I P. Drew \& J. Heritage (eds.), Talk at Work (s. 268-301). Cambridge University Press.

Greatbatch, D. (1998): "Conversation Analysis: Neutralism in British News Interviews". I A. Bell og P. Garrett (eds.), Approaches to Media Discourse. Oxford Blackwell.

Hjarvard, S. (1995): Nyhedsmediernes rolle i det politiske demokrati. Medieudvalget. Statsministeriet. http://imv.au.dk/ smu/.www.html (uden sidetal)

Hutchby, I. (1996): Confrontation Talk: Arguments, Asymmetries, and power on talk radio. Mahwah, N.J.: Lawrence Erlbaum Associates.

Hutchby, I. \& Wooffitt, R. (1998): Conversation Analysis. Principles, practices and applications. Polity Press.

Koch, H. (1945/1991): Hvad er demokrati. København: Nordisk Forlag a.s.. 5. udgave, 2. oplag.

McQuail, D. (1992): Media Performance: Mass Communication and the Public Interest. London: Sage.

Nielsen, M. Femø (1999): "Grundbegreber i nyere samtaleanalyse". I A. Holmen et al. (eds.), NyS 25, s. 9-55. Dansklærerforeningen.

Nielsen, M. Femø (2001): Replik til journalistikken-mikroanalyse af medieinterviewet. Akademisk Forlag.

Nielsen, M. Femø (2003): Fournalistisk balance (upubliceret).

Nielsen, M. Femø (2004): "Orkestrering af tv-debatter". I Peter Widell \& Mette Kunøe (red.) (2003), 9. Møde om Udforskningen af Dansk Sprog, Århus Universitet, s. 214230.

Nofsinger, R.E. (1988/89): "Lets talk about the record': Contending over topic redirection in the Rather/Bush interview". I Research on Language and Social Interaction. Vol. 22, s. 273-292.

Nylund, M. (2000): Iscenesatt Interaktion: Strukturer och strategier $i$ politiska mediesamtal. Helsingfors. Svenska Litteratursällskapet.

Pomerantz, A. (1984): "Agreeing and disagreeing with assessments: some features of preferred/dispreferred turn shapes". I Research on Language and Social Interaction. Vol. 22, s. 293-314.

Pomerantz, A. (1988/89): "Constructing skepticism: Four devices used to engender the audiences skepticism". I Research on Language and Social Interaction. Vol. 22, s. 293314.

Sacks, H. (1995): Lectures on conversation. Vol. 2. Blackwell Publishers.

Schegloff, E.A. (1980): Preliminaries to Preliminaries: "Can I ask you a question?" I D. Zimmerman og C. West (eds.), Social Inquiry. Vol. 50, nr. 3-4, s. 104-152.

Schegloff, E.A. (1982): "Discourse as an interactional achievement: some uses of "uh huh" and other things that come between sentences". I D. Tannen (ed.), Analy- zing discourse: Text and talk. Georgetown University Roundtable on Languages and linguistics. Georgetown University Press, s. 71-93.

Schegloff, E.A. (1992): "On talk and its institutional occasions". I P. Drew \& J. Heritage (eds.): Talk at Work (s. 101-134). Cambridge University Press,

Steensig, J. (2001): Sprog i virkeligheden - bidrag til en interaktionel lingvistik. Århus Universitetsforlag.

Zimmerman. D. (1998): "Identity, Context and Interaction". I C. Antaki \& S. Widdicombe (eds.), Identities in Talk (s. 87-106). London: Sage Publications.

\section{Noter}

1. http://www.cfje.dk/cfje/Lovbasen.nsf/ID/ LB05022306, kapitel 3, §10.

2. Nielsen 2001, s. 24.

3. Se artikel af Mie Femø Nielsen for en introduktion til konversationsanalyse.

4. Når deltagerne taler i overlap, står deres tale i klammer under hinanden. En pause angives med (.) og ind-/udånding med $. h / h$.

5. Heritage \& Greatbatch 1991.

6. Pomerantz 1984.

7. Footingbegrebet er introduceret af Erving Goffman (1981) og behandler deltageres involvering i interaktion. Ved skift af footing kan man med forskellige produktionsformater skifte imellem at tale på egne og på andres vegne. En interviewer kan bruge footingskift til at fremsætte vurderinger og synspunkter og stadig være objektiv, fordi han tillægger dem en tredje part.

8. Heritage \& Greatbatch 1991, s. 101-2.

9. Steensig 2001, s. 72.

10. Steensig 2001, s. 76.

11. Steensig 2001, s. 76. Baseret på Schegloff 1996a.

12. Ordstyrerens fagter er angivet under talen.

13. Steensig 2001, s. 135.

14. En tur består af en eller flere turkonstruktionsenheder, som hver ender med et muligt færdiggørelsespunkt, hvor der er mulighed for respons fra tilhøreren, eller der er relevans for turskifte til næste taler (Schegloff 1982).

15. Hutchby 1996, Femø 2004.

16. Turpar er taleture, der normativt er forbundet i en sekvens, hvor første pardel efterlader en åben plads til den anden pardel, der, hvis den ikke udfyldes konventionelt, er mærkbart fraværende (Hutchby \& Wooffitt 1998).

17. Schegloff \& Sacks 1973, Nielsen 2001, s. 58.

18. Nielsen 2001, s. 97.

19. Hutchby 1995, Sacks 1992, vol. 2.

20. Maynard 1985 citeret i Hutchby 1995, s. 48.

21. Nylund 2000, s. 124.

22. Gaik 1992. 